\title{
More caution needs in study design and method selection for "In vitro antibacterial effect of Deconex and sodium hypochlorite against bacterial taxa isolated from dental units" [Letter]
}

This article was published in the following Dove Press journal:

Infection and Drug Resistance

\section{Amir Emami ii \\ Neda Pirbonyeh (ii) \\ Fatemeh Javanmardi (iD}

Department of Microbiology, Burn and Wound Healing Research Center, Shiraz University of Medical Sciences, Shiraz, Fars, Iran
Correspondence: Amir Emami Department of Microbiology, Burn and Wound Healing Research Center, AmirAl-Momenin Burn and Wound Healing Hospital, Shiraz University of Medical Sciences, Shiraz, Fars, PO Box 719875436, Iran

Email emami.microbia@gmail.com

\section{Dear editor}

Recently, we have meticulously read the paper by Amin et al ${ }^{1}$ about the effect of Deconex and sodium hypochlorite on bacterial taxa isolated from dental faculty units in Ahvaz Jundishapure University of Medical Sciences. Firstly, we are fortunate that a specialist evaluates axiomatic fact. According to the confirmed antimicrobial effect of deconex product by Borer Chemie AG based on its certificates (VAH: German Association for Applied Hygiene, CE1250 by Switzerland and EC-certificate by registration number 33818$),{ }^{2}$ no more tests are needed for confirmation, especially by non-specialized sections. These tests are merely administered by oversight organizations such as Food and Drug Administration (FDA) or infection control committee of Ministry of Health and Medical Education from approved and specialized laboratories. Currently, according to the categories of international FDA, alcoholic-based compounds are approved to be used as safe disinfectants especially in moderate conditions (not high-dose infections). Accordingly, it would be baseless to verify such compounds. Based on obvious data and the mechanism of alcoholic compounds on microbial proteins, no valid reports have been recently submitted about the formation of resistance against alcoholic-based disinfectants, not even in prolonged applications. ${ }^{3}$

In case of any report on inappropriate decontamination findings, the cause might have been an incorrect application of reagents according to the international and company recommendations (it is mentioned briefly in the introduction part).

In addition, there are some confusing explanations in the method section which are against standard techniques and Clinical Laboratory Standard Institute (CLSI) guideline. The authors claim that as many as 100 samples were taken from different parts of 10 different units from different divisions. Due to the dispersion of the sampling, how did the authors conclude the greatest contamination persists in all 10 units of 3 studied (!!!) divisions (oral medicine, root canal therapy and surgery) with the rest of 9 other units from other divisions?

In the first step for isolates detection, hot dyeing (or Ziehl-Neelsen) method is introduced, but this method is used in phenotypic tests only for mycobacteria, 
not for the detection of routine growth bacteria, which must be detected by gram stain technique. ${ }^{4,5}$ Then, this method of staining is not applicable for screening of the studied isolates.

Based on many standards and reports, disinfection agents must be evaluated by Phénol coefficient technique, not by minimal inhibitory concentration (MIC) technique which has been wrongly applied. ${ }^{6}$ In the Phénol coefficient technique, we can examine the effect of the time and strength of the studied compound without changing its nature, especially the standard concentration of the studied compounds. In addition, according to the CLSI standard method for MIC, the inoculation of bacteria to the microtiter plate wells is limited in volume and in number. Maximum volume and number of bacteria test in microdilution technique is $5 \mu \mathrm{L}$ with the highest concentration of $5 \times 10^{4-5} \mathrm{CFU} / \mathrm{mL}$, while the authors declared that total of $50 \mu \mathrm{L}$ of the bacterial sample have been inoculated with concentration of $1 \times 10^{6}$ to the test wells, which is twice more than the permitted standard. ${ }^{7}$ Given that the Journal of Infection and Drug Resistance is a valuable source of methods and data related to this filed, it is requested that articles and methods submitted for publication be more precisely reviewed.

\section{Disclosure}

The authors report no conflicts of interest in this communication.

\section{References}

1. Amin M, Ardaneh M, Hashemzadeh M, Dezfuli AA, JafarZadeh E. In vitro antibacterial effect of deconex and sodium hypochlorite against bacterial taxa isolated from dental units. Infect Drug Resist. 2019;12:805.

2. SQS C. EC- Certificate. Swiss Association for Quality and Managment System SQS. 2013. Available from: www.borer.ch/fileadmin/_ migrated/content_uploads/RL_93-42-EWG_1_CE_1250_EN.pdf. Accessed August 08, 2019.

3. Cariz J. Hospital superbug becoming resistant to alcohol disinfectants. Am Assoc the Adv Sci. 2018;1(1):1-5.

4. Harada K. The nature of mycobacterial acid-fastness. Stain Technol. 1976;51(5):255-260.

5. Coico R. Gram staining. Curr Protoc Microbiol. 2005; Appendix 3 (Appendix 3c): $1-5$.

6. Jensen V, Jensen E. Determination of the phenol coefficient of disinfectants by the cover-slip method. J Hyg (Lond). 1933;33(4):485494

7. CLSI. Performance standards for antimicrobial susceptibility testing. Clin Lab Stand Inst. 2016;1(26):62-65.

Dove Medical Press encourages responsible, free and frank academic debate. The content of the Infection and Drug Resistance 'letters to the editor' section does not necessarily represent the views of Dove Medical Press, its officers, agents, employees, related entities or the Infection and Drug Resistance editors. While all reasonable steps have been taken to confirm the content of each letter, Dove Medical Press accepts no liability in respect of the content of any letter, nor is it responsible for the content and accuracy of any letter to the editor.

\section{Publish your work in this journal}

Infection and Drug Resistance is an international, peer-reviewed openaccess journal that focuses on the optimal treatment of infection (bacterial, fungal and viral) and the development and institution of preventive strategies to minimize the development and spread of resistance. The journal is specifically concerned with the epidemiology of antibiotic resistance and the mechanisms of resistance development and diffusion in both hospitals and the community. The manuscript management system is completely online and includes a very quick and fair peerreview system, which is all easy to use. Visit http://www.dovepress.com/ testimonials.php to read real quotes from published authors. 